\title{
Temperature and Photoperiod Influence Flowering and Morphology of Four Petunia spp.
}

\author{
Ryan M. Warner ${ }^{1}$ \\ Department of Horticulture, Michigan State University, A234 Plant and Soil \\ Science, East Lansing, MI 48824
}

Additional index words. development rate, photoperiodism, Petunia axillaris, Petunia exserta, Petunia $\times$ hybrida, Petunia integrifolia

\begin{abstract}
Flowering and morphology of four Petunia Juss. spp. [P. axillaris (Lam.) Britton et al., $P$. exserta Stehmann, $P$. integrifolia (Hook.) Schinz \& Thell., and $P$. $\times$ hybrida Vilm.] were evaluated in response to photoperiod and temperature. Photoperiod responses were evaluated under 9-h short days (SD), 9-h photoperiod plus 4-h night-interruption lighting (NI), or a 16-h photoperiod supplemented with high-pressure sodium lamps (16-h HPS). All species flowered earlier under NI than SD and were classified as facultative (quantitative) long-day plants. Increasing the daily light integral within long-day treatments increased flower bud number for $P$. axillaris only. In a second experiment, crop timing and quality were evaluated in the temperature range of 14 to $26^{\circ} \mathrm{C}$ under 16-h HPS. The rate of progress toward flowering for each species increased as temperature increased from 14 to $26{ }^{\circ} \mathrm{C}$, suggesting the optimal temperature for development is at least $26^{\circ} \mathrm{C}$. The calculated base temperature for progress to flowering varied from $0.1^{\circ} \mathrm{C}$ for $P$. exserta to $5.3^{\circ} \mathrm{C}$ for $P$. integrifolia. Flowering of $P$. axillaris and $P$. integrifolia was delayed developmentally (i.e., increased node number below the first flower) at $14^{\circ} \mathrm{C}$ and $17^{\circ} \mathrm{C}$ or less, respectively, compared with higher temperatures. Petunia axillaris and $P$. integrifolia flower bud numbers decreased as temperature increased, whereas $\boldsymbol{P}$. $\times$ hybrida flower bud number was similar at all temperatures. The differences in crop timing and quality traits observed for these species suggest that they may be useful sources of variability for petunia breeding programs.
\end{abstract}

Petunia (Petunia $\times$ hybrida) has long been a popular bedding plant with a wholesale value of $\$ 110$ million in 2008 (U.S. Department of Agriculture-National Agricultural Statistics Service, 2009). Petunia is a facultative long-day plant for flowering (Adams et al., 1998; Piringer and Cathey, 1960), although Petunia 'Wave Purple' has been described as an obligate long-day plant (Erwin, 2006). Petunias are often produced in northern climates during the late winter and early spring months, when light levels are low and ambient photoperiods are short, necessitating the use of supplemental lighting to promote flowering. Breeding efforts have been successful in reducing the strength of the photoperiodic response (i.e., reducing the delay in flowering for plants grown under short days compared with night-interruption long days) of some cultivars (Pemberton and Roberson, 2006), although no day-neutral cultivars are known. In addition to photoperiod, daily light integral (DLI) can influence earliness of flowering by reducing node

\footnotetext{
Received for publication 9 Oct. 2009. Accepted for publication 19 Jan. 2010.

I acknowledge the assistance of greenhouse technician Mike Olrich and undergraduate students Jim Moylan and Erica Helewski, and financial support from the USDA Floriculture and Nursery Research Initiative and from growers supporting Michigan State University floriculture research.

${ }^{1}$ Assistant Professor. e-mail warnerry@msu.edu.
}

number below the first flower (Armitage and Tsujita, 1979; Erwin and Warner, 2002; Warner and Erwin, 2003), referred to as a facultative irradiance response (Mattson and Erwin, 2005). A survey of 40 herbaceous ornamental species identified 10 species with a facultative irradiance response, 28 species that were irradiance indifferent, and two species in which node number below the first flower increased with increasing DLI (Mattson and Erwin, 2005). Adams et al. (1999) determined that increasing DLI reduced the length of the juvenile phase of petunia 'Express Blush Pink'.

The time required for developmental processes to occur in plants is primarily a function of accumulated thermal time, often quantified as degree-days (Bonhomme, 2000). The rate of progress toward a developmental event (such as appearance of a new node, or flowering) increases linearly between a species-specific base temperature $\left(\mathrm{T}_{\text {base }}\right)$, in which development rate is nil, and an optimum temperature (Adams et al., 1997). At temperatures above the optimum, development rate declines. Growing plants at the optimum temperature for development rate, resulting in minimum production time, may be undesirable because it often results in reductions in crop quality. For example, increasing temperature from 14 to $26{ }^{\circ} \mathrm{C}$ decreased Campanula carpatica Jacq. time to flower, but also decreased flower number and flower size (Niu et al., 2001).

The genus Petunia consists of 14 currently recognized species (Stehmann et al., 2009) native to temperate and subtropical South America. Wild relative species may hold potential for improvement of the cultivated petunia $(P . \times$ hybrida $)$. Petunia $\times$ hybrida is derived from a cross between $P$. axillaris and $P$. integrifolia (Stehmann et al., 2009), and Petunia spp. are generally cross-compatible (Ando et al., 2001; Watanabe et al., 1996, 2001), although fertility varies widely between parental species combinations. Little information is available concerning the influence of light and temperature on floral timing and crop quality characteristics of wild Petunia spp. Therefore, the objectives of work presented here were to: 1) determine the photoperiodic response group for $P$. $\times$ hybrida 'Mitchell' and three wild relative species; and 2) evaluate the influence of photoperiod and temperature on crop timing and quality parameters.

\section{Materials and Methods}

Expt. 1: Photoperiod treatments. Petunia axillaris (PI 28546; obtained from the USDA Ornamental Plant Germplasm Center, Columbus, $\mathrm{OH}$ ), $P$. exserta (provided by Dr. Robert Griesbach, USDA-ARS), $P$. $\times$ hybrida 'Mitchell' (provided by Dr. David Clark, Univ. of Florida), and P. integrifolia (Diane's Flower Seeds, Ogden, UT) seeds were sown in 128 -cell $(10 \mathrm{~mL}$ cell volume; one seed per cell) trays on 3 Feb. 2008 and placed in a greenhouse at $23 \pm 1.0{ }^{\circ} \mathrm{C}(24-\mathrm{h}$ mean $\pm \mathrm{SD}$ ) under intermittent mist. When two true leaves had unfolded, seedlings were transplanted into $10-\mathrm{cm}$ diameter round pots $(450 \mathrm{~mL})$ containing $(\mathrm{v} / \mathrm{v}) 70 \%$ peatmoss, $21 \%$ vermiculite, and $9 \%$ perlite (Sure-Mix; Michigan Grower Products, Galesburg, MI) and placed into one of three treatments. Treatments were: short days (SD; a truncated 9-h photoperiod obtained by covering plants with opaque cloth from 1700 to $0800 \mathrm{HR}$ daily), long days provided as night interruption lighting (NI; 9-h photoperiod obtained by covering plants with opaque cloth from 1700 to $0800 \mathrm{HR}$ daily plus $3 \mu \mathrm{mol} \cdot \mathrm{m}^{-2} \cdot \mathrm{s}^{-1}$ night-interruption lighting from incandescent lamps from 2200 to $0200 \mathrm{HR}$ ), or a $16-\mathrm{h}$ photoperiod (16-h HPS; ambient light plus $90 \mu \mathrm{mol} \cdot \mathrm{m}^{-2} \cdot \mathrm{s}^{-1}$ from high-pressure sodium lamps from 0600 to $2200 \mathrm{HR})$ at $20 \pm 1^{\circ} \mathrm{C}(24-\mathrm{h}$ mean \pm SD) until flowering. Photosynthetic photon flux at the top of the plant canopy was measured in each treatment every $10 \mathrm{~s}$ with a 10-photodiode line quantum sensor (Apogee Instruments, Logan, UT) connected to a data logger (CR10; Campbell Scientific, Logan, UT). Hourly averages were stored and used to calculate DLI. The mean DLI for the $\mathrm{SD}, \mathrm{NI}$, and HPS treatments was 11.4, 11.5, and $16.5 \mathrm{~mol} \cdot \mathrm{m}^{-2} \cdot \mathrm{d}^{-1}$, respectively.

Expt. 2: Temperature effects on crop timing and quality. Seeds of the same species were sown and transplanted as described previously and then were placed into one of five greenhouse compartments set to a constant temperature of $14,17,20,23$, or $26^{\circ} \mathrm{C}$ under a 16-h photoperiod supplemented with HPS lamps as described for Expt. 1. Air temperature in each treatment was measured 
by a Type E thermocouple (TT-E-40; Omega Engineering, Stamford, CT) placed in an aspirated tube. Thermocouples were connected to a data logger (CR10) and data were recorded every $10 \mathrm{~s}$. Hourly averages were stored. Actual mean temperatures \pm SD during the experimental period were $14.0 \pm 0.75,17.0$ $\pm 0.50,20.0 \pm 1.1,22.6 \pm 0.64$, and $25.7 \pm$ $0.60{ }^{\circ} \mathrm{C}$. Vapor pressure deficit was maintained between 0.7 and $1.0 \mathrm{kPa}$ at each temperature by steam injection.

Plant culture. Plants were irrigated as needed with reverse osmosis-treated well water supplemented with $\left(\mathrm{mg} \cdot \mathrm{L}^{-1}\right)$ : 125 nitrogen, 13 phosphorus, 125 potassium, 15 calcium, 1 iron, 0.1 boron and molybdenum, and 0.5 manganese, zinc, and copper (MSU Special; GreenCare Fertilizers, Kankakee, IL).

Experimental design, data collection, and analysis. Both experiments were fully factorial split plot designs with plants arranged in two replicated blocks of 10 plants each per species per main plot. In Expt. 1, photoperiod treatment constituted the main plot with three levels, whereas in Expt. 2, temperature was the main plot with five levels. Species was the subplot in each experiment. Block effects were not significant in any case. Therefore, data were pooled for subsequent analysis. In both experiments, at anthesis of the first flower, the date was recorded and the number of nodes on the primary shoot below the open flower, number of visible flower buds (greater than $3 \mathrm{~mm}$ in length), and the number of lateral branches (greater than $5 \mathrm{~cm}$ in length) were determined. Flowering rate in response to temperature was calculated as $1 /$ days to flower. Analyses of variance and means separations [Tukey's $\operatorname{HSD}_{(0.05)}$ ] were conducted using the general linear model procedure of the SPSS 17.0 for Windows statistical software package (SPSS Inc., Chicago, IL). Regression analyses were performed with Sigmaplot 8.0 (Systat Software, Chicago, IL). Linear regression analysis was conducted on flowering rate as a function of temperature. The slope $\left(b_{1}\right)$ and $y$-intercept $\left(b_{0}\right)$ of each equation were used to calculate $\mathrm{T}_{\text {base }}\left(-\mathrm{b}_{0} / \mathrm{b}_{1}\right)$ and degree-days to flowering $\left(1 / b_{1}\right)$ for each species.

\section{Results}

Species and photoperiod treatment interacted to impact time to flower, number of nodes below the first flower, and flower bud number (Table 1). All species flowered earlier in time and with fewer nodes under NI than SD (Table 1). The increase in node number below the first flower under SD compared with NI ranged from 14 nodes for $P$. exserta (from 12 to 26 nodes) to 22 nodes for $P$. integrifolia (from 18 to 40 nodes). Petunia exserta formed the fewest nodes below the first flower regardless of treatment. Growing under 16-h HPS did not reduce node number below the first flower or time to flower for any species compared with NI (Table 1). Although P. exserta formed fewer nodes below the first flower than $P$. axillaris or $P$. integrifolia under NI, time to flower was

Table 1. Influence of short days (SD; 9-h photoperiod), long days provided as a 4-h night interruption (NI), or long days provided by 16-h lighting with high-pressure sodium lamps (16-h HPS) on time to flower (in days), number of nodes below the first flower (nodes), number of visible flower buds at first flowering (buds), and the number of lateral branches at first flowering (branches; greater than $5 \mathrm{~cm}$ in length) for four Petunia spp. ${ }^{2}$

\begin{tabular}{|c|c|c|c|c|c|}
\hline Species & Photoperiod & Time to flower (d) & Nodes (no.) & Buds (no.) & Branches (no.) \\
\hline \multirow[t]{3}{*}{ P. axillaris } & SD & $70 \mathrm{~b}$ & $37.6 \mathrm{~b}$ & $36.7 \mathrm{~b}$ & $10.0 \mathrm{~b}$ \\
\hline & NI & $49 \mathrm{a}$ & $17.7 \mathrm{a}$ & $14.2 \mathrm{a}$ & $8.4 \mathrm{a}$ \\
\hline & 16-h HPS & $45 \mathrm{a}$ & $20.0 \mathrm{a}$ & $33.7 \mathrm{~b}$ & $7.7 \mathrm{a}$ \\
\hline \multirow[t]{3}{*}{ P. exserta } & $\mathrm{SD}$ & $64 \mathrm{~b}$ & $25.8 \mathrm{~b}$ & $24.9 \mathrm{~b}$ & $8.8 \mathrm{~b}$ \\
\hline & NI & $52 \mathrm{a}$ & $12.3 \mathrm{a}$ & $13.4 \mathrm{a}$ & $7.2 \mathrm{~b}$ \\
\hline & 16-h HPS & $53 \mathrm{a}$ & $13.0 \mathrm{a}$ & $14.9 \mathrm{a}$ & $4.9 \mathrm{a}$ \\
\hline \multirow[t]{3}{*}{ P. $\times$ hybrida } & $\mathrm{SD}$ & $71 \mathrm{~b}$ & $36.5 \mathrm{~b}$ & $39.3 \mathrm{~b}$ & $16.4 \mathrm{a}$ \\
\hline & NI & $63 \mathrm{a}$ & $22.3 \mathrm{a}$ & $23.1 \mathrm{a}$ & $15.1 \mathrm{a}$ \\
\hline & 16-h HPS & $59 \mathrm{a}$ & $24.1 \mathrm{a}$ & $28.4 \mathrm{a}$ & $12.0 \mathrm{a}$ \\
\hline \multirow[t]{3}{*}{ P. integrifolia } & $\mathrm{SD}$ & $70 \mathrm{~b}$ & $40.3 \mathrm{~b}$ & $30.9 \mathrm{a}$ & $13.2 \mathrm{~b}$ \\
\hline & NI & $49 \mathrm{a}$ & $18.3 \mathrm{a}$ & $25.7 \mathrm{a}$ & $6.8 \mathrm{a}$ \\
\hline & 16-h HPS & $48 \mathrm{a}$ & $19.1 \mathrm{a}$ & $31.7 \mathrm{a}$ & $8.4 \mathrm{a}$ \\
\hline \multicolumn{2}{|l|}{ Source } & \multicolumn{4}{|c|}{ Significance } \\
\hline \multicolumn{2}{|l|}{ Species } & $* * * \mathrm{y}$ & $* * *$ & $* * *$ & $* * *$ \\
\hline \multicolumn{2}{|c|}{ Photoperiod } & $* * *$ & $* * *$ & $* * *$ & $* * *$ \\
\hline \multicolumn{2}{|c|}{ Species $\times$ photoperiod } & $* * *$ & $*$ & $*$ & NS \\
\hline
\end{tabular}

zValues followed by different letters indicate significant differences across photoperiod treatment within a species as determined by Tukey's $\operatorname{HSD}_{(0.05)}$. Means are based on two blocks of 10 plants each.

$\mathrm{y}_{\mathrm{NS}}, *$ and $* * *$ indicate nonsignificance or significance at $P<0.05$ or 0.001 , respectively.

similar for all three species (Table 1), indicating a lower node appearance rate for P. exserta.

Species and photoperiod treatment interacted to impact flower bud production. All species except $P$. integrifolia produced more flower buds at first flowering under SD than NI (Table 1). Growing plants under 16-h HPS increased flower bud number compared with NI for $P$. axillaris only. Branch number at first flowering varied by species and by photoperiod treatment. Petunia axillaris and $P$. integrifolia produced more branches under SD than under NI or 16-h HPS (Table 1). Photoperiod treatment did not significantly influence $P$. ×hybrida branch production, whereas $P$. exserta produced fewer branches under 16-h HPS than SD or NI.

Increasing temperature from 14 to $26^{\circ} \mathrm{C}$ decreased time to flower for all species (Fig. 1). The time to flower response to temperature was best fit by a quadratic polynomial equation for each species. The rate of progress toward flowering increased as a linear function of temperature between 14 and $26^{\circ} \mathrm{C}$ for all four species (Table 2). Species varied in calculated $\mathrm{T}_{\text {base, }}$, ranging from $0.1{ }^{\circ} \mathrm{C}$ for P. exserta to $5.3^{\circ} \mathrm{C}$ for $P$. integrifolia (Table 2 ). Because the flowering rate continued to increase throughout the range of temperatures evaluated, the optimum temperature for rate of progress to flowering is at least $26{ }^{\circ} \mathrm{C}$ for all species.

The effect of temperature on node number below the first flower varied by species (Table 3). Petunia axillaris node number was similar as temperature decreased from 26 to $17{ }^{\circ} \mathrm{C}$, but increased as temperature further decreased to $14{ }^{\circ} \mathrm{C}$. Petunia integrifolia node number was similar from 26 to 20 ${ }^{\circ} \mathrm{C}$, but increased as temperature declined to 17 or $14{ }^{\circ} \mathrm{C}$. In contrast, $P$. exserta node number was greater at 26 than $14{ }^{\circ} \mathrm{C}$ (Table 3 ).

Flower bud number response to temperature varied by species (Table 3 ). For example,
$P$. axillaris and $P$. integrifolia flower number declined as temperature increased, whereas $P$. $\times$ hybrida flower number was similar at all temperatures. Petunia axillaris bud number was more temperature-sensitive than the other species, declining from 42.5 buds at $14{ }^{\circ} \mathrm{C}$ to 20.1 buds at $26^{\circ} \mathrm{C}$, a $53 \%$ decrease. Petunia $\times$ hybrida and $P$. integrifolia branch number decreased as temperature increased from 14 to $26{ }^{\circ} \mathrm{C}$ (Table 3). Petunia exserta branch number was lower at 20 and $23{ }^{\circ} \mathrm{C}$ than at $14{ }^{\circ} \mathrm{C}$.

\section{Discussion}

All four species responded as facultative (quantitative) long-day plants, forming fewer nodes below the first flower under NI compared with SD (Table 1), although flowering occurred under all photoperiods. The similar photoperiodic responses of the evaluated $\mathrm{Pe}$ tunia spp. are perhaps not surprising considering that the genus is small with only 14 species and occurs naturally in a relatively narrow geographic area. In contrast, species of the genus Hibiscus L., with 250 to 300 species (Bates, 1965) distributed widely throughout the world, exhibit a wide range of photoperiodic responses, including obligate and facultative short-day, day-neutral, and facultative and obligate long-day species (Warner and Erwin, 2001). However, despite the similar and relatively strong photoperiodic response of the Petunia spp. evaluated here, it may be possible to use these species to breed for petunia cultivars with reduced photoperiod sensitivity, because interspecific hybrid populations derived from these species exhibited wide variation for floral timing traits such as node number below the first flower and days to flower (Warner and Walworth, 2010). Also, evaluation of 51 seed-propagated trailing petunia cultivars revealed that although flowering time of all cultivars was accelerated by nightinterruption lighting compared with ambient 


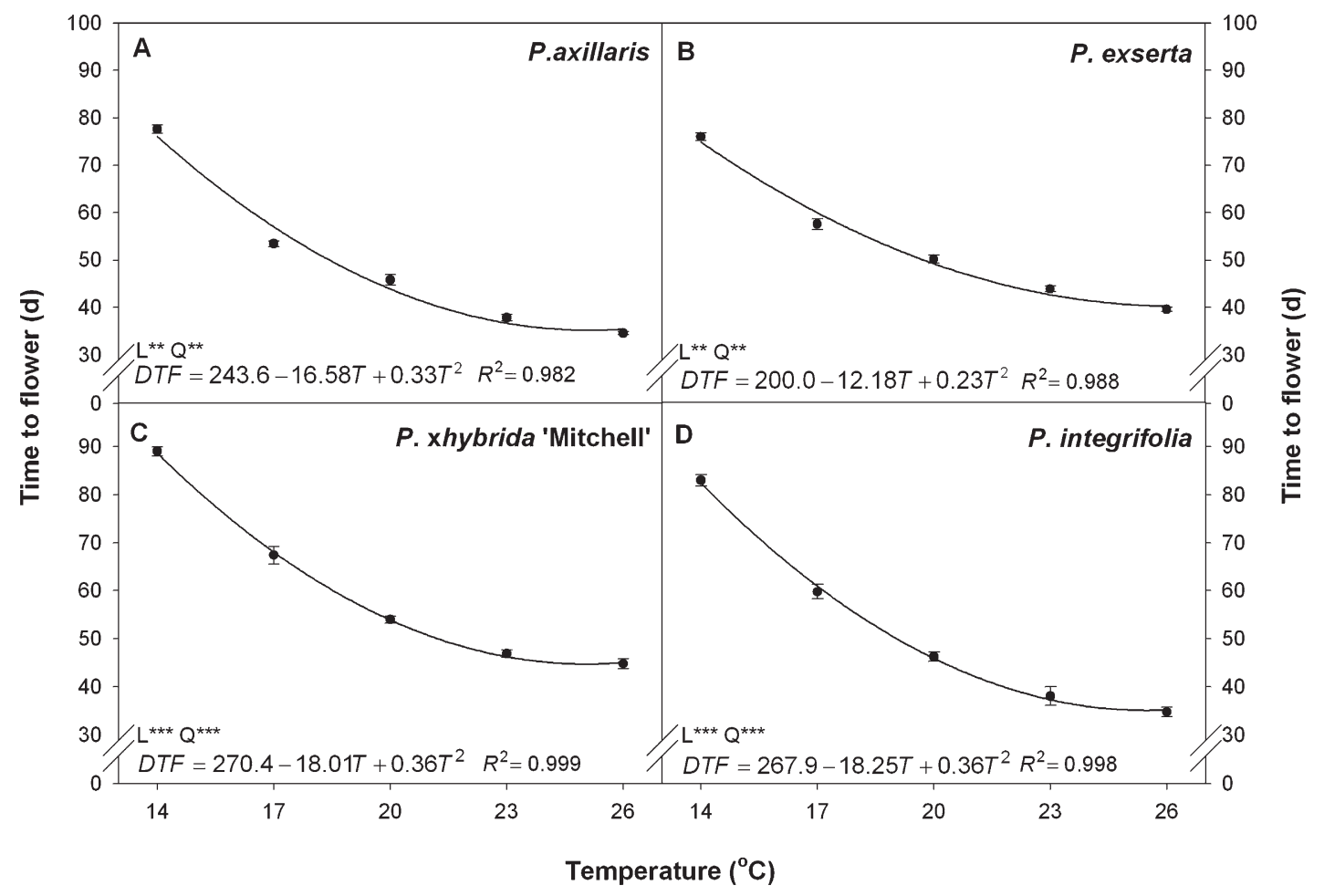

Fig. 1. Influence of temperature on days to flower for (A) Petunia axillaris, (B) P. exserta, (C) P. $\times$ hybrida 'Mitchell', and (D) P. integrifolia. Also shown are the significance levels of linear (L) and quadratic (Q) regressions of the data with ** and *** representing significance at $P<0.01$ and 0.001 , respectively, and predictive models for days to flower $(D T F)$ in response to temperature $(T)$. Error bars represent se about the mean.

Table 2. Linear regression coefficients and calculated values for base temperature ( $\left.\mathrm{T}_{\text {base }}\right)$ for progress to flowering and thermal time (in degree-days) to flowering for four Petunia spp. ${ }^{2}$

\begin{tabular}{lcccc}
\hline Species & $\mathrm{b}_{0}$ & $\mathrm{~b}_{1}$ & Degree-days to flowering & $\mathrm{T}_{\text {base }}\left({ }^{\circ} \mathrm{C}\right)$ \\
\hline P. axillaris & -0.0048 & 0.0013 & 769 & 3.7 \\
P. exserta & -0.0010 & 0.0010 & 1000 & 0.1 \\
P. xhybrida & -0.0015 & 0.0010 & 1000 & 1.5 \\
P. integrifolia & -0.0080 & 0.0015 & 667 & 5.3 \\
\hline
\end{tabular}

${ }^{2}$ Time to flower data were converted to rate of progress to flowering (1/days to flower) for linear regression analysis with temperature as the independent variable. Equations are in the form Rate $=\mathrm{b}_{0}+\mathrm{b}_{1} T$ where $\mathrm{b}_{0}$ is the y-intercept, $\mathrm{b}_{1}$ is the slope, and $T$ is temperature. Degree-days to flowering and $\mathrm{T}_{\text {base }}$ values are calculated from linear regression models for data from plants grown between 14 and $26^{\circ} \mathrm{C}$.

short photoperiods, the acceleration ranged from $32 \mathrm{~d}$ for 'Tidal Wave Hot Pink' to only 4 d for 'Ramblin' Burgundy Chrome' (Pemberton and Roberson, 2006).

Within the long-day treatments, increasing the DLI from the NI $\left(11.5 \mathrm{~mol} \cdot \mathrm{m}^{-2} \cdot \mathrm{d}^{-1}\right)$ to $16-\mathrm{h}$ HPS $\left(16.5 \mathrm{~mol} \cdot \mathrm{m}^{-2} \cdot \mathrm{d}^{-1}\right)$ treatment increased flower bud number for P. axillaris only, from 14.2 to 33.7 buds. Increasing flower bud numbers with increased DLI have been observed in other species, although the DLI resulting in the maximum flower production varies widely. Increasing DLI from 6.7 to 8.9 $\mathrm{mol} \cdot \mathrm{m}^{-2} \cdot \mathrm{d}^{-1}$ increased Hibiscus radiatus flower bud number from seven to 10 buds (Warner and Erwin, 2003), although further increasing DLI (up to $16.7 \mathrm{~mol} \cdot \mathrm{m}^{-2} \cdot \mathrm{d}^{-1}$ ) did not further increase flower bud number. Faust et al. (2005) evaluated several bedding plant species under mean DLIs of $5,12,19$, and $43 \mathrm{~mol} \cdot \mathrm{m}^{-2} \cdot \mathrm{d}^{-1}$. Begonia $\times$ semperflorens-cultorum L. 'Vodka Cocktail' flower number was highest at a DLI of $19 \mathrm{~mol} \cdot \mathrm{m}^{-2} \cdot \mathrm{d}^{-1}$ or higher, whereas Catharanthus roseus L. 'Pacific Lilac', Petunia ×hybrida 'Apple Blossom', Tagetes erecta L.
'American Antigua Orange', and Zinnia elegans L. 'Dreamland Rose' flower numbers were highest at $43 \mathrm{~mol} \cdot \mathrm{m}^{-2} \cdot \mathrm{d}^{-1}$.

The optimal temperature for minimizing time to flower appears to be at least $26^{\circ} \mathrm{C}$ for each Petunia species evaluated here, because time to flower decreased with increasing temperature from 14 to $26^{\circ} \mathrm{C}$, similar to results for P. Xhybrida 'Snow Cloud', which had an optimum temperature of $25{ }^{\circ} \mathrm{C}$ (Kaczperski et al., 1991). Differences in time to flower across species at a given temperature were explained by interactions between degree-days to flower and $\mathrm{T}_{\text {base. For }}$. Forample, both $P$. exserta and $P$. Xhybrida required 1000 degree-days to flower (Table 2). However, $P$. exserta $\mathrm{T}_{\text {base }}$ is lower and consequently accumulates more degree-days per day than P. $\times$ hybrida. Similarly, although $P$. axillaris had a higher degree-day requirement for flowering than $P$. integrifolia, days to flower at a given temperature were generally higher for $P$. integrifolia because it had a higher $\mathrm{T}_{\text {base }}$. Although $\mathrm{T}_{\text {base }}$ is a useful variable for modeling crop timing responses to temperature, it is not a good predictor for low-temperature stress tolerance. For example, $P$. exserta had the lowest $\mathrm{T}_{\text {base }}$ of the four species evaluated here; however, it was also the most freezingsensitive of the four species after cold acclimation (Walworth and Warner, 2009).

The increase in time to flower at low temperatures for $P$. axillaris (at $14{ }^{\circ} \mathrm{C}$ ) and $P$. integrifolia $\left(14\right.$ and $\left.17^{\circ} \mathrm{C}\right)$, compared with warmer temperatures, was attributable both to slower leaf unfolding rates and an increase in the number of nodes formed below the first flower. Mattson and Erwin (2003) previously noted that increasing temperature from 12 to $24{ }^{\circ} \mathrm{C}$ decreased petunia 'Avalanche Pink', 'Dreams Rose', and 'Wave Purple' node number below the first flower. In contrast, Salvia splendens F. Sello ex Roem \& Schult. 'Vista Red' and Tagetes patula L. 'Bonanza Yellow' developed a similar number of nodes below the first flower, regardless of temperature between 14 and $26{ }^{\circ} \mathrm{C}$ (Moccaldi and Runkle, 2007). Petunia exserta node number below the first flower was greater at 26 than $14{ }^{\circ} \mathrm{C}$, indicating that not all Petunia spp. experience developmental delay in flowering at cool temperatures.

Increasing temperature reduced flower bud number of $P$. axillaris and $P$. integrifolia (Table 3). Similarly, flower bud number of nine grandiflora-type $P$. $\times$ hybrida cultivars declined as temperature increased from 14 to $26{ }^{\circ} \mathrm{C}$ (Warner, unpublished data). In contrast, $P$. $\times$ hybrida 'Mitchell' exhibited much greater thermal stability for floral production across the evaluated temperature range, because flower bud number did not decline with increasing temperature (Table 3 ). This 
Table 3. Effect of temperature on the number of nodes below the first flower (nodes), number of visible flower buds at first flowering (buds), and number of lateral shoots (branches) for four Petunia spp. grown under a $16-\mathrm{h}$ photoperiod. ${ }^{\mathrm{z}}$

\begin{tabular}{|c|c|c|c|c|}
\hline Species & $\begin{array}{c}\text { Temperature } \\
\left({ }^{\circ} \mathrm{C}\right)\end{array}$ & $\begin{array}{c}\text { Nodes } \\
\text { (no.) }\end{array}$ & $\begin{array}{l}\text { Buds } \\
\text { (no.) }\end{array}$ & $\begin{array}{c}\text { Branches } \\
\text { (no.) }\end{array}$ \\
\hline \multirow[t]{5}{*}{ P. axillaris } & 14 & 29.1 & 42.5 & 11.1 \\
\hline & 17 & 21.0 & 39.4 & 8.8 \\
\hline & 20 & 20.1 & 31.7 & 7.7 \\
\hline & 23 & 19.4 & 24.9 & 9.1 \\
\hline & 26 & 19.3 & 20.1 & 8.2 \\
\hline Significance & & $* * * y$ & $* * *$ & $* * *$ \\
\hline$P_{\text {linear }}$ & & NS & $* * *$ & NS \\
\hline$P_{\text {quadratic }}$ & & $*$ & $*$ & NS \\
\hline \multirow[t]{5}{*}{ P. exserta } & 14 & 12.6 & 22.7 & 11.1 \\
\hline & 17 & 13.1 & 16.4 & 8.4 \\
\hline & 20 & 14.6 & 22.2 & 6.5 \\
\hline & 23 & 14.1 & 30.3 & 6.8 \\
\hline & 26 & 15.0 & 24.0 & 9.0 \\
\hline Significance & & $*$ & $* * *$ & $* * *$ \\
\hline$P_{\text {linear }}$ & & $*$ & NS & NS \\
\hline$P_{\text {quadratic }}$ & & NS & NS & $* *$ \\
\hline \multirow[t]{5}{*}{ P. $\times$ hybrida } & 14 & 24.3 & 32.2 & 12.4 \\
\hline & 17 & 23.7 & 33.5 & 12.7 \\
\hline & 20 & 25.7 & 39.7 & 11.1 \\
\hline & 23 & 22.9 & 37.6 & 9.9 \\
\hline & 26 & 21.9 & 42.6 & 8.9 \\
\hline Significance & & $*$ & $* * *$ & $* * *$ \\
\hline$P_{\text {linear }}$ & & NS & $*$ & $*$ \\
\hline$P_{\text {quadratic }}$ & & NS & NS & $*$ \\
\hline \multirow[t]{5}{*}{ P. integrifolia } & 14 & 25.3 & 39.0 & 10.6 \\
\hline & 17 & 24.7 & 31.9 & 10.1 \\
\hline & 20 & 17.4 & 32.6 & 6.0 \\
\hline & 23 & 15.5 & 24.3 & 6.5 \\
\hline & 26 & 14.6 & 20.9 & 6.6 \\
\hline Significance & & $* * *$ & $* * *$ & $* * *$ \\
\hline$P_{\text {linear }}$ & & $*$ & $* *$ & NS \\
\hline$P_{\text {quadratic }}$ & & NS & NS & NS \\
\hline
\end{tabular}

${ }^{\mathrm{z}}$ Means are based on two blocks of 10 plants each.

$\mathrm{y}_{\mathrm{NS}}, * * *$ and $* * *$ indicate nonsignificance or significance at $P<0.05,0.01$, or 0.001 , respectively.

genotype may be a useful genetic source for improving floral production of modern $P$. $\times$ hybrida cultivars at higher temperatures.

Collectively, these results indicate that although all four species were classified as facultative long-day plants, considerable variation exists in crop timing and quality traits in response to light and temperature, and these species may therefore be useful sources of genetic variation that can be used in Petunia breeding programs.

\section{Literature Cited}

Adams, S.R., P. Hadley, and S. Pearson. 1998. The effects of temperature, photoperiod, and photosynthetic photon flux on the time to flowering of petunia 'Express Blush Pink'. J. Amer. Soc. Hort. Sci. 123:577-580.

Adams, S.R., S. Pearson, and P. Hadley. 1997. The effects of temperature and light integral on the time to flowering of pansy cv. Universal Violet (Viola ×wittrockiana Gams.). Ann. Bot. (Lond.) 80:107-112.

Adams, S.R., S. Pearson, P. Hadley, and W.M. Patefield. 1999. The effects of temperature and light integral on the phases of photoperiod sensitivity in Petunia $\times$ hybrida. Ann. Bot. (Lond.) 83:263-269.

Ando, T., M. Nomura, J. Tsukahara, H. Watanabe, H. Kokubun, T. Tsukamoto, G. Hashimoto, E. Marchesi, and I.J. Kitching. 2001. Reproductive isolation in a native population of Petunia sensu Jussieu (Solanaceae). Ann. Bot. (Lond.) 88:403-413.

Armitage, A.M. and M.J. Tsujita. 1979. The effect of supplemental light source, illumination and quantum flux density on the flowering of seedpropagated geraniums. J. Hort. Sci. 54:195198.

Bates, D.M. 1965. Notes on the cultivated Malvaceae 1. Hibiscus. Baileya 13:56-130.

Bonhomme, R. 2000. Bases and limits to using 'degree-day' units. Eur. J. Agron. 13:1-10.

Erwin, J. 2006. Factors affecting flowering in ornamental plants, p. 7-48. In: Anderson, N.O. (ed.). Flower breeding and genetics. Springer, Dordrecht, The Netherlands.

Erwin, J.E. and R.M. Warner. 2002. Determination of photoperiodic response group and effect of supplemental irradiance on flowering of several annual bedding plant species. Acta Hort. 580: 95-99.
Faust, J.E., V. Holcombe, N.C. Rajapakse, and D.R. Layne. 2005. The effect of daily light integral on bedding plant growth and flowering. HortScience 40:645-649.

Kaczperski, M.P., W.H. Carlson, and M.G. Karlsson. 1991. Growth and development of Petunia $\times$ hybrids as a function of temperature and irradiance. J. Amer. Soc. Hort. Sci. 116:232237.

Mattson, N.S. and J.E. Erwin. 2003. Temperature affects flower initiation and development rate of Impatiens, Petunia, and Viola. Acta Hort. 624:191-197.

Mattson, N.S. and J.E. Erwin. 2005. The impact of photoperiod and irradiance on flowering of several herbaceous ornamentals. Sci. Hort. 104: 275-292.

Moccaldi, L.A. and E.S. Runkle. 2007. Modeling the effects of temperature and photosynthetic daily light integral on growth and flowering of Salvia splendens and Tagetes patula. J. Amer. Soc. Hort. Sci. 132:283-288.

Niu, G., R.D. Heins, A. Cameron, and W. Carlson. 2001. Temperature and daily light integral influence plant quality and flower development of Campanula carpatica 'Blue Clips', 'Deep Blue Clips', and Campanula 'Birch Hybrid'. HortScience 36:664-668.

Pemberton, H.B. and W.R. Roberson. 2006. Winter greenhouse performance and photoperiod responses of 51 cultivars of seed-grown trailing petunias. HortScience 41:1065 (abst.).

Piringer, A.A. and M.M. Cathey. 1960. Effect of photoperiod, kind of supplemental light and temperature on the growth and flowering of petunia plants. Proc. Amer. Soc. Hort. Sci. 76:649-660.

Stehmann, J.R., A.P. Lorenz-Lemke, L.B. Freitas, and J. Semir. 2009. The genus Petunia, p. 1-28. In: Gerats, T. and J. Strommer (eds.). Petunia: Evolutionary, developmental and physiological genetics. Springer, New York, NY.

U.S. Department of Agriculture-National Agricultural Statistics ServiceFloriculture crops 2008 summary. 10 Dec. 2009. <http://usda.mannlib. cornell.edu/usda/current/FlorCrop/FlorCrop-0423-2009.pdf>.

Walworth, A.E. and R.M. Warner. 2009. Differential cold acclimation ability of Petunia spp. HortScience 44:1219-1222.

Warner, R.M. and J.E. Erwin. 2001. Variation in floral induction requirements of Hibiscus spp. J. Amer. Soc. Hort. Sci. 126:262-268.

Warner, R.M. and J.E. Erwin. 2003. Effect of photoperiod and daily light integral on flowering of five Hibiscus sp. Sci. Hort. 97:341-351.

Warner, R.M. and A.E. Walworth. 2010. Quantitative inheritance of crop timing traits in interspecific hybrid Petunia populations and interactions with crop quality parameters. J. Hered. doi: 10.1093/jhered/esp131.

Watanabe, H., T. Ando, S.-I. Iida, A. Suzuki, K.-i. Buto, T. Tsukamoto, G. Hashimoto, and E. Marchesi. 1996. Cross compatibility of Petunia cultivars and $P$. axillaris with native taxa of Petunia in relation to their chromosome number. J. Jpn. Soc. Hort. Sci. 65:625-634.

Watanabe, H., T. Ando, T. Tsukamoto, G. Hashimoto, and E. Marchesi. 2001. Cross-compatibility of Petunia exserta with other Petunia taxa. J. Jpn. Soc. Hort. Sci. 70:33-40. 